\title{
Risk Management of Zakat Maal Supervision in the Fintech Era based on Literature Review
}

\author{
Arivatu Ni'mati Rahmatika and Tholib Hariono \\ KH. Abdul Wahab Hasbullah University
}

Paper to be presented at International Conference of Zakat 2018

15-16 November, Universitas Gadjah Mada, Yogyakarta, Indonesia

\section{ABSTRACT}

Cybercrime in Indonesia is the first tier in the world and Indonesia also grabs a second level on hacking activities, and both are in line with the rapid development of technology in these decades. There is no rule in Islam to avoid the development of science in this case technology, but Islam still regulate the obligation of tithe as long as humans are still alive in the world, zakat maal is an obligation in Islam with the specific rules, zakat maal is considered able to solve the problem of income inequality. Further technological sophistication is also considered as a tool for the implementation of such obligations. This study aims to address the risks that are likely or even inevitable in the activities of zakat maal in the fintech era. Library research is the main way in conducting this research to answer a problem. This study resulted in a finding in the form of an application that is connected with the zakat institution BAZNAS shade and detail how its use includes calculation of nisab zakat, distribution of zakat, control of distribution and prevention of fraud that may occur. This is the first time in the history of the study, because this study discusses in detail how to overcome and overcome the risks that exist in the use of technology to implement the obligations of zakat maal.

Keywords: Risk Management, Application, Zakat maal

\section{INTRODUCTION}

Cybercrime is a crime by using technological sophistication including computers and the internet. Both walk together in committing a crime. While the sophistication of technology and the internet can no longer be avoided. Almost all Indonesian citizens have more mobile phones than water and others. So that crime also follows the current developments. Similar to technological sophistication that is growing rapidly, the majority of Muslims are also growing, and the Islamic ummah has a consequence of choosing him as Islam, namely carrying out an obligation. The obligations that must be carried out by the Islamic ummah have been stated in the pillars of Islam and the rules in al-qur'an, including the obligation of zakat and the obligation to study.

Based on two examples of these obligations, the sophistication of technology will always accompany the activities of Muslims. Therefore, technological sophistication is expected to be able to support every obligation of the Islamic ummah which is a consequence. So that the sophistication of technology is required to have elements of consumer protection in the form of risk management in its sophistication, consumer protection is meant here is protection in the form of guaranteeing the implementation of a Muslim's obligation in the form of zakat and studying, while the risk management referred to here is to minimize errors in the implementation of a Muslim's activities. Consumer protection refers to the obligation of every Muslim in the form of zakat, in the religion of Islam, the obligation to pay zakat is in two things, namely zakat fitrah and zakat maal. Zakat fitrah is carried out when Romadhon with zakat in the form of staple 
food, while zakat maal is carried out when a Muslim is considered to have been able to carry out, which in Islam is called a treasure has reached the Nisab. Risk management plays a role in preventing activities that are possible / certain to occur in the fulfillment of obligations. This can be explained by the supervision and openness of the parties concerned in an activity. Supervision can be exemplified by the level of security and openness that can be exemplified by the report of each activity.

Consumer protection and risk management are two things that can be said to be almost the same when referring to their function, both of which function to carry out activities so that they always run safely and smoothly and achieve a goal. While the goal of a Muslim is to carry out an obligation in his religion. Furthermore, as already mentioned, the technological era cannot be avoided anymore, so in this case it can be stated that technology, risk management and consumer protection are three things that cannot be separated. Especially for a Muslim, in carrying out the obligations in this age, these things must be dealt with in line with the obligations determined by religion. Risk management is considered as a way to continue to carry out the obligation of tithing and not forgetting technological advances, so there is a need for a special way to do this.

\section{LITERATURE REVIEW}

Zakat is one of the pillars of Islam, zakat ranks third in the pillars of Islam. History has noted, that the obligation of zakat has been obliged in the second year of migration. Whereas the provisions, rosulullah in his hadith have explained that the amount is one sha 'and the size of the majority of scholars is different, some consider that it is equal to $1 / 6$ liter or $1 / 3$ liter of Egyptian containers with a size equal to 2,167 grams.

Zakat fitrah is not the only zakat in Islam, there is an obligation of zakat maal in
Islam. Al-quran explains that there are 4 types of things that are obligatory to be zakatized, namely gold and silver, plants and fruits, trading businesses and mining goods. While the management of zakat since the time of the Prophet Muhammad, the time of Khulafaur Rosyidin, the Caliphate of Islam and the modern era has always experienced development, but from all developments, the most important is from the side of recording. Namely Q.S AlBaqoroh 282:

"O ye who believe! If you do not bless in cash for a specified time, you should write it down. and let a writer among you write it correctly. and let the writer not be willing to write it as God taught it, they should write, and let the person who owes it imagine (what will be written), and let him fear Allah the Lord, and do not reduce any of his debt. if the debtor is a person who is weak in reason or weak (his condition) or he is not able to imitate himself, then let his guardian imagine it honestly and witness with two witnesses from men (among you). if there are no two men, then it is possible for a man and two women of witnesses to whom you are pleased, so that if someone forgets, then someone reminds him. the witnesses should not be reluctant (give information) if they are called; and do not be tired of writing the debt, small or large until the deadline for paying it. that is, it is more just in the sight of Allah and strengthens the witness and is closer to not (causing) your doubts. (Write your mu'amalah), except if mu'amalah it trades the cash that you run between you, then there is no sin for you, (if) you don't write it. and witness if you sell and buy; and do not let writers and witnesses trouble each other difficult. if you 
do (that is), then surely it is a ungodliness to you. and fear Allah; Allah teaches you; and Allah knows all things." (Al-Baqoroh: 282)

The phase in modeling zakat risk management is 5 vases, namely: (Guide to risk management of baznas). The first phase begins with the formation of context, this can be done by means of literature review and interviews with experts and practitioners in their fields, then carried out risk identification by determining risk groups so that the risks and impacts can be identified. Risk measurement is the third phase, in this phase, measurement of several criteria and measurement scales is used in accordance with the needs of the zakat institution. This phase is used to measure the level of likelihood, impact, vulnerability and speed of risk occurrence. After the three phases were carried out, followed by risk evaluation, in this phase a validation meeting was held for practitioners. The last phase is the treatment of risk. Which in this phase risk mitigation is carried out according to the level of risk.

Identifying a risk is not an easy thing, because this relates to decision making both in companies that aim at profit or not. Every organization/company, both profit and nonprofit oriented can be said to face different risks, including social risk. The social risk referred to here is the risk associated with the community around the organization. If the company is a profitoriented company/organization, then the social risk is how the ability of the company/organization to be friendly to both the community and the environment, in contrast to companies/organizations that are not profit oriented, the social risk is how the charity relationship to surrounding community. Because of this, the zakat institution designs a concept of risk management, from risk identification to management using the enterprise risk management (ERM) method with a modified Committee of Sponsoring Organizations of the Treadway Commission
(COSO) approach. Broadly speaking, the method includes risk identification, measurement, risk mapping, risk mitigation strategy planning.

Identifying risk is the first step in the zakat institution. By implementing this, the zakat institution will get various information about risks, and their impact and how quickly these risks occur, it is recommended in ways that will be done to deal with these risks. Based on risk identification, various types of risks are found, namely operational risk, property risk, risk of amil \& volunteer, Risk Muzakki \& mustahik, Risk of zakat transfer between countries.

\section{RESEARCH METHODOLOGY}

The consumer protection of the zakat institution is the basis of the consideration of the writing of this research, and risk management is used as the basis for the establishment of a zakat maal application. The aim is to provide a risk control by using technological sophistication without forgetting the obligation to carry out religious orders in the form of zakat maal. This study uses a qualitative approach by applying library research methods commonly referred to as library research. Literature-based research is a form of research that uses literature as an object of study. This approach is in accordance with the conditions of Islamic financial institutions, due to the limited Islamic compliance in terms of managing the conflict. The data used in this study are secondary data, namely books, magazines and written documents. In addition to those already mentioned, this study also uses article articles taken from research journals related to this research. There has not been found a study that discusses the application of risk management in order to keep running religious orders without forgetting the sophistication of technology. While to answer the problem, the analytical technique used is cultural theme analysis 
(discovering cultural theme). The technique requires data, in the form of interviews from various seminars carried out to zakat policy makers, which can then be found in more detailed data in the form of problems within the zakat institution that relate to risk management, so that with data library support and compound analysis then obtained an application to reduce the risk that might occur in the implementation of the obligation of zakat maal with the use of technological sophistication. The results of discovering cultural themes are then considered to be used as material to answer this research question.

\section{RESULT AND DISCUSSION}

Here is a table of the types of risks and how to handle them / reduce them based on the application for zakat maal.

Table 1. Outline of risks and handling

\begin{tabular}{|c|c|}
\hline Risk Type & $\begin{array}{l}\text { Risk management / } \\
\text { reduction }\end{array}$ \\
\hline Operational Risk & $\begin{array}{l}\text { The application is equipped } \\
\text { with a concept in which there } \\
\text { is a choice of mustahiq carried } \\
\text { out by muzakki in order to } \\
\text { distribute zakat appropriately. } \\
\text { If one mustahik recorded is } \\
\text { evenly distributed, it will } \\
\text { automatically close. }\end{array}$ \\
\hline Property Risk & $\begin{array}{l}\text { Muzakki filled in wealth, the } \\
\text { system will automatically } \\
\text { calculate the zakat }\end{array}$ \\
\hline $\begin{array}{l}\text { Amil and } \\
\text { volunteer risk }\end{array}$ & $\begin{array}{l}\text { Amil which in this case is a } \\
\text { zakat institution, controls } \\
\text { through the registration of a } \\
\text { muzakki account or mustahik } \\
\text { account in the zakat } \\
\text { institution, with the hope of } \\
\text { distributing precisely and } \\
\text { evenly }\end{array}$ \\
\hline $\begin{array}{l}\text { Muzakki and } \\
\text { mustahik risks }\end{array}$ & $\begin{array}{l}\text { Muzakki has the right to } \\
\text { choose which zakat will be } \\
\text { distributed, and mustahik has } \\
\text { the right to receive if it is } \\
\text { included in the zakat } \\
\text { institution }\end{array}$ \\
\hline $\begin{array}{l}\text { Risk of zakat } \\
\text { transfer between } \\
\text { Countries }\end{array}$ & $\begin{array}{l}\text { If there are foreign members, } \\
\text { it will apply }\end{array}$ \\
\hline
\end{tabular}

Source: Author

Operational risk management in this study is realized by creating a simple application based on technological sophistication with the aim of facilitating the muzakki and mustahiq in carrying out the process of implementing the obligation of zakat and distribution. Here is an overview of the steps in the application 
Figure 1. Zakat mal operational risk management

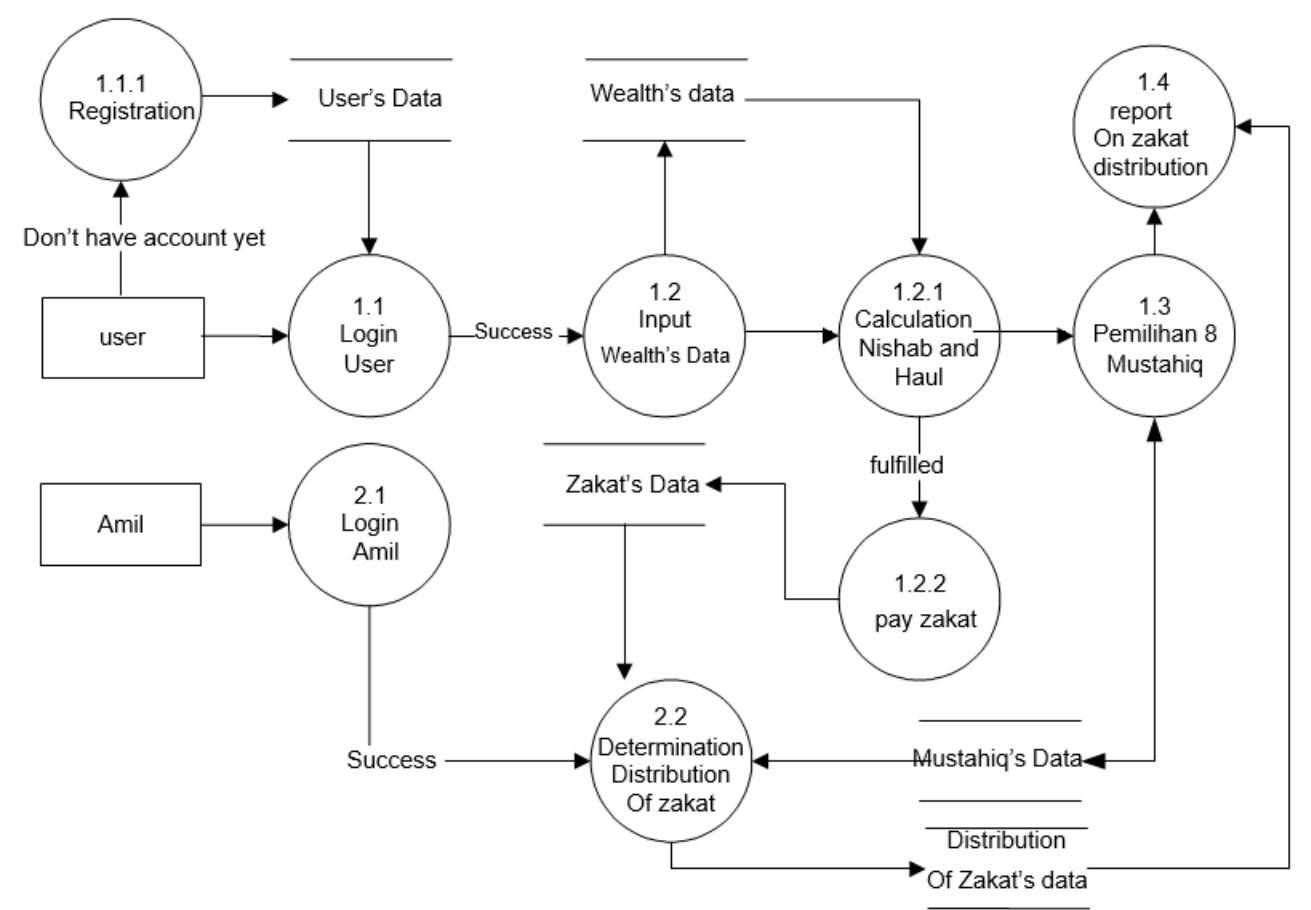

Image description: From the user side to enter the system must log in (1.1) first, if the user does not have an account can register (1.1.1) to create a new account. After successfully logging in the user can enter the amount of assets (1.2) owned, then the system will calculate the nishab and haul (1.2.1), if the nishab and haul have been fulfilled the user will get information on how much zakat must be paid so that the user can make payment zakat (1.2.2). Zakat payment data will be stored in Zakat Data. Besides that another process that can be done by the user is to determine the selection of 8 mustahiq (1.3) so that the distribution of zakat is as desired. Users can obtain information on zakat distribution reports (1.4) from the Amil side to enter the system starting with login (2.1). Amil can distribute zakat (2.2). This provision of zakat distribution is based on zakat data, namely data that stores user zakat payments, and mustahiq data that was previously chosen by the user. The proceeds from the distribution of zakat will be stored in the data of zakat distribution.

Property risk handling refers to technological sophistication in this research in the form of an obligation for muzakki to fill in wealth which then automatically the system will bring up how much zakat is issued. So that the calculation will be less likely to be found in the error of zakat. In addition to the Nisab, the system will also display the Haul option with the aim that the conditions for issuing zakat maal can be fulfilled. This Nisab calculation is based on the religious rules that have been explained in the literature review discussed above.

Figure 2. Property risk management

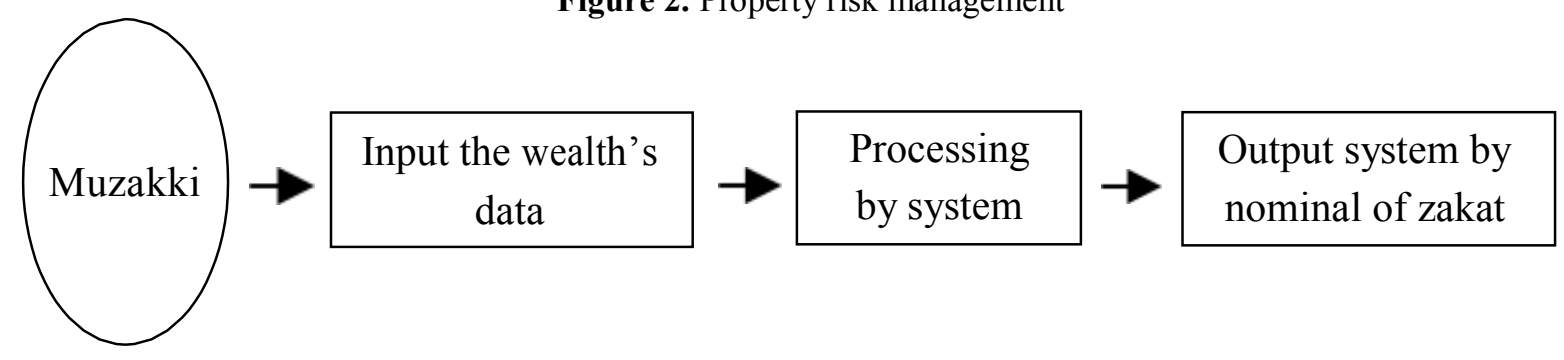


The picture below will explain the risk management of amil / volunteer, namely in the form of amil controlling the members of the zakat institution which consists of two types of members namely members of muzakki and members of mustahiq. So that amil will easily control the incoming zakat funds and easily channel them to the rightful ones. As well as reducing the likelihood of miscalculation and distribution errors.

Figure 3: Risk Management of volunteers

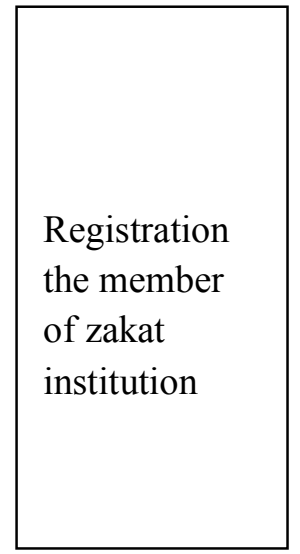

Handling the risk of muzakki and mustahiq in this case in the form of the implementation of the mandate in the form of proper distribution to those who are
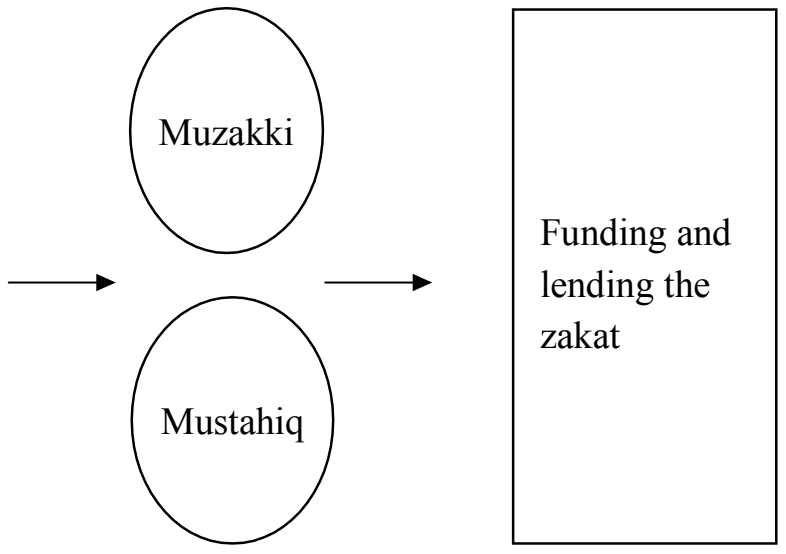

entitled to receive zakat, which distribution uses data that is already available in the zakat institution.

Figure 4. Risk Management of Muzakki and mustahiq

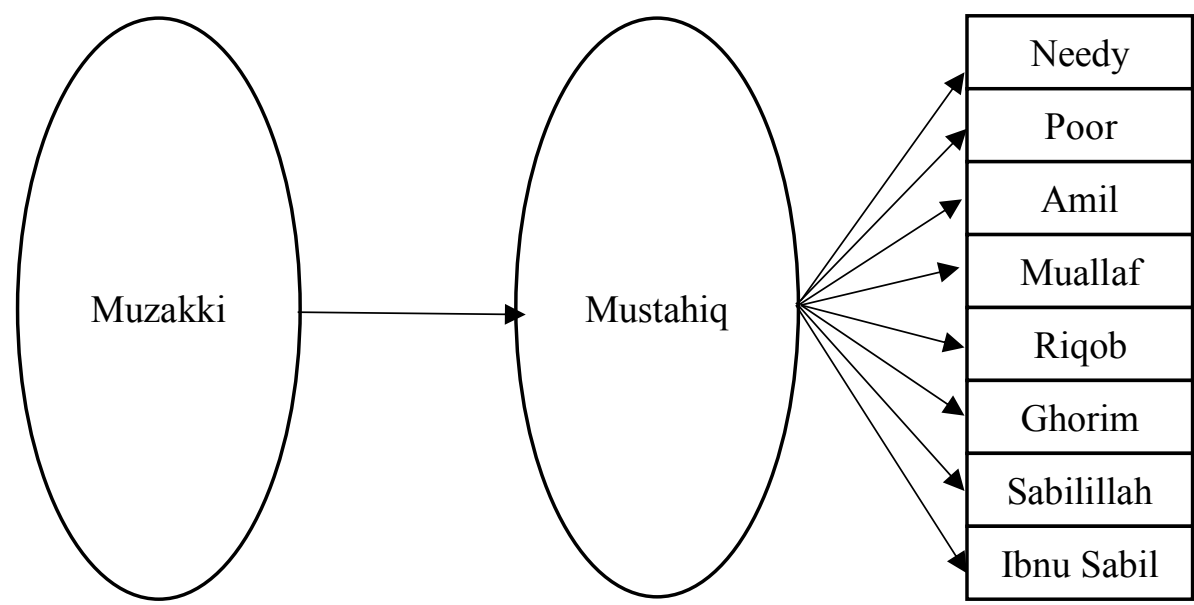

\section{CONCLUSION}

The conclusion of this study is an application that aims to reduce the possibility of risk that will occur. The risk raised in this study is the operational risk that the researcher considers as the main reference in this study. Because of all the risks that exist, the operational risk that underlies the existence of an application whose function is to reduce / mitigate risk.

\section{REFERENCES}

Abdelmawla, M. A. (2014). "The Impacts of Zakat and Knowledge on Poverty Alleviation in Sudan: An Empirical 
Investigation (1990-2009)", Journal of Economic Cooperation and Development, 35 (4), pp. 61-84

Haneef, S. S. S. \& Mahmud, M. W. (2012). "Issues in Contemporary Zakat: A Juristic Analytical Evaluation",Kuala Lumpur: IIUM Press

Khan, M. Akram (2005). "Comments on A. Azim Islahi \& M. Obaidullah: Zakat on Stocks: Some Unsettled Issues", Journal of King Abdul Aziz University: Islamic Economics, 18(1), pp. $41-42$

Risk Management by BAZNAS
Arivatu Ni'mati Rahmatika

KH. Abdul Wahab Hasbullah University Indonesia

Tholib Hariono

KH. Abdul Wahab Hasbullah University Indonesia 